\title{
Exercise and sport do not trigger seizures in children and adolescents with epilepsy in school settings
}

\section{Exercício e esporte não desencadeiam crises em crianças e adolescentes com epilepsia em ambientes escolares}

Rodrigo Luiz Vancini', Marília dos Santos Andrade², Cássia Regina Vancini-Campanharo², Claudio Andre Barbosa de Lira ${ }^{4}$

Dear Editor,

Recently, a study ${ }^{1}$ has claimed that children and teenagers who suffer from epilepsy may experience prolonged seizures while exercising or practicing any sport. People with epilepsy are at higher risk of sudden death than healthy subjects ${ }^{2}$, and participation in sports/exercise, in rare cases, can trigger seizures ${ }^{3}$. However, the bulk of scientific evidence indicates that exercise and sports should be encouraged for everyone with epilepsy, children and teenagers included. Previous studies have shown the positive effects of exercise, such as a decrease in seizure frequency, cardiovascular status improvement, and increase in life quality, self-esteem, and well-being .

Despite the benefits of physical activity, people with epilepsy, unfortunately, often are advised against participating in sports and exercise, mostly because of fear, overprotection, and lack of knowledge about the disease $e^{3,4,5}$.

Thus, schools and educational institutions need to plan educational programs, targeting health professionals, family members, caregivers, students, teachers, and school employees, in order to improve their knowledge about exercise and epilepsy and provide appropriate care and assistance to students with epilepsy.

\section{References}

\footnotetext{
1. Hartman AL, Devore CD, Doerrer SC. Rescue medicine for epilepsy in education settings. Pediatrics. 2016;137(1). https://doi.org/10.1542/peds.2015-3876

2. Scorza FA, Cavalheiro EA, Costa JC. Sudden cardiac death in epilepsy disappoints, but epileptologists keep faith. Arq Neuropsiquiatr. 2016;74(7):570-3. https://doi.org/10.1590/0004-282X20160086

3. Capovilla G, Kaufman KR, Perucca E, Moshé SL, Arida RM. Epilepsy, seizures, physical exercise, and sports: a report from the ILAE
}

Task Force on Sports and Epilepsy. Epilepsia 2016;57(1):6-12. https://doi.org/10.1111/epi.13261

4. Vancini RL, Benedito-Silva AA, Sousa BS, Silva SG, Souza-Vancini MI, Vancini-Campanharo CR et al. Knowledge about epilepsy among health professionals: a cross-sectional survey in Sao Paulo, Brazil. BMJ Open. 2012;2(2):e000919. https://doi.org/10.1136/bmjopen-2012-000919

5. Vancini RL, Lira CAB, Silva SG, Scorza FA, Silva AC, Vieira D et al. Evaluation of physical educators' knowledge about epilepsy. Arq Neuropsiquiatr. 2010;68(3):367-71. https://doi.org/10.1590/S0004-282X2010000300007

\footnotetext{
'Universidade Federal do Espírito Santo, Vitória, Centro de Educação Física e Desportos, Vitória ES, Brasil;

${ }^{2}$ Universidade Federal de São Paulo, Departamento de Fisiologia, São Paulo SP, Brasil;

${ }^{3}$ Universidade Federal de São Paulo, Escola Paulista de Enfermagem, São Paulo SP, Brasil;

«Universidade Federal de Goiás, Faculdade de Educação Física e Dança, Laboratório de Avaliação do Movimento Humano, Setor de Fisiologia Humana e do Exercício, Goiânia GO, Brasil.

Correspondence: Claudio Andre Barbosa de Lira; Faculdade de Educação Física e Dança - Universidade Federal de Goiás; Avenida Esperança s/n, Campus Samambaia; 74690-900 Goiânia GO, Brasil; E-mail: andre.claudio@gmail.com

Conflict of interest: There is no conflict of interest to declare.

Received 15 June 2017; Accepted 23 June 2017.
} 